\title{
新しい手法の塩水濃度法による流量測定 ${ }^{\dagger}$
}

\author{
切田篤* - 小宮 勤 一** \\ Flow Measurement by the Reformed Salt Dilution Method \\ Atsushi Kirita* and Kin-ichi KomIyA**
}

The salt dilution method is suitable for measurement of flow in open channel. However, the customary method is based on the temporary and inaccurate data obtained by some preparatory measurements, and accordingly the method is unreliable in spite of the complicated procedures.

We present in this paper fine conductivity data of brine, useful for the salt dilution method.

Utilising the data, the salt dilution method becomes more reasonable and simpler, without the preliminary experiments and the procedure of calibration, which are necessary for the customary method.

Moreover, these conductivity data improve the accuracy and reproduction of flow measurements.

Some practical ideas to achieve uniform distribution of injected brine are proposed.

Key Words: flow measurement, salt dilution method, conductivity, dilution, vortex sheet injection

\section{1.はじめに}

現在考えられている，さまざまな流量測定法の中 で, 希釈法 (dilution method) は他の多くの測定法と 異り, 流路断面形状や直管長, 流速分布等の流れの状 熊に影響されずに流量測定が行えるという特長をむっ ており，特に開水路の流量測定法として優れた特質を もっている.

本論文では，希釈法の中で，試薬として食塩を用い

†第 22 回計測自動制御学会学術講演会で発表（昭 58.7）

* 計量研究所 茨城県新治郡桜村梅園 1-1-4

** 九州工業大学 北九州市戸畑区仙水町 1-1

* Nationnal Research Laboratory of Metrology, Niihari-gun, Ibaraki

** Kyushu Institute of Technology, Kitakyushu (Received June 15, 1984)

(Revised January 17, 1985)
る塩水濃度法の実施手法の改良を四るために，食塩水 の導電率特性を広範囲の濃度と温度に適用できる実験 式の形で提示した. この実験式に基いた新しい手法に よる流量測定実験を行った結果, 塩水濃度法による測 定手順の著しい簡素化と再現性の向上を図れることが 確認できた. またての実験を通じて, 食塩水の注入方 法の比較検討を行い, 流量測定精度の向上を図った.

なお本論文中では，塩化ナトリウム，およびその水 溶液む，便宜上，食塩あるいは食塩水と表記した。ま た実験には専売公社発売の食塩を使用し, 食塩 $1 \mathrm{~mol}$ を $58.450 \mathrm{~g}$ として測定を行っている.

\section{2. 塩水濃度法}

\section{1 塩水濃度法の原理}

ある定常流の流量 “ $Q$ ” を測定する場合, その流れ が自然の状態ですっている食塩の濃度（導電率を食塩 に換算した濃度）を “C $C_{0} ”$ とする. この流れに試薬と して濃度 “ $C_{1}$ ” が既知である濃食塩水を一定の流量 “ $q$ ” で注入する. そしてての濃食塩水が十分に拡散 し, 濃度分布が均一になった下流で, 流れの食塩濃度 が “ $C_{2}$ ” に上昇しているとき, 注入前後の食塩の量の 関係より(2.1)式が導かれる (Fig. 1).

$$
\begin{aligned}
& C_{0} \cdot Q+C_{1} \cdot q=C_{2} \cdot(Q+q) \\
& Q=q \cdot \frac{C_{1}-C_{2}}{C_{2}-C_{0}} \fallingdotseq q \cdot \frac{C_{1}}{\Delta C} \\
& \text { ただし }, \Delta C=C_{2}-C_{0}, C_{1} \gg C_{2}, C_{0}
\end{aligned}
$$

したがって求める流量は (2.2) 式で表わされ, 濃食塩

$$
\mathrm{c}_{1} ; \mathrm{q}
$$

INJECTION

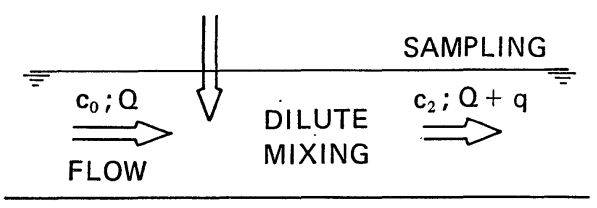

Fig. 1 The principal of dilution method 
水の濃度と注入量及び流れの濃度変化量より流量が求 められる，乙の方法では，乙れらの量を精度良く求め るととと，注入した濃度食塩水が十分均一に拡散され ることが，安定した流量測定を行うための必要条件と なる。

\section{2 従来の塩水濃度法}

(2.2) 式に基づいて塩水濃度法による流量測定を行 う場合, 食塩水の電解導電率は濃度にほぼ比例して変 化するので，原理的にはその電解導電率を測定するて とにより濃度（(2.2)式の $C_{0}, C_{1}, C_{2}, \Delta C$ など）が求 められる. しかし現実には食塩水の電解導電率は温度。 によって大きく変化する上，食塩水の導電率に関する

\section{3. 食塩水の導電率特性}

\section{1 塩水濃度法と導電率データ}

塩水濃度法を実施する場合，試薬として調製する濃 食塩水は，流れの状態によっても異るが，通常数十 $l$ 〜数 $\mathrm{m}^{3}$ 程度の量を使用するので，その濃度や温度を 一定の值汇調製するととは難しい，したがって，大ま かに調製した湢食塩水の電解導電率と温度より，その 濃度を正しく求め直す必要があり，しかむその測定 精度は (2.2)式が示すように，そのまま流量測定精度 につながる，また，試薬注入前後の測定流の食塩濃度 を電解導電率と温度より求める場合, 電解導電率の温 データ（特に温度特性）が十分に得ら れないととにより，任意の食塩水の濃 度を, その電解導電率と温度より求め るととはかなり難しい.

このため従来は, 流量測定を行う直 前に, 注入.用に調製した濃食塩水と， 測定流より採取した水を用いて現場で 希釈実験を行い, 電解導電率またはコ ンダクタンスの変化量と希釈率の関係 をデータにとり，てのデータを基準に 用いて濃度の值を:介さずに直接に電解 導電率またはコンダクタンスの変化量 より流量を算出していた．てのように 従来の手法に上る食塩水濃度法は測定 の度に異なったデータに基づいて行わ れ，しかすそのデータは，現場での不 確実な希釈実験により得ているので, 手間のかかる割には不確実で再現性に む乏しい流量測定方法であった ${ }^{1) ~ 3) . ~}$

今まで塩水濃度法に合理的な取り組 みが行われなかった理由として，従来 は溶液の電解導電率を現場で精度良く 求めるととが難しかったため, コンダ クタンスの測定で代用する場合が多か ったととと, 食塩水の導電率関する データが十分に得られなかったとと， の二つが考えられる.しかし前者につ いては測定技術の進歩により, 現場で む容易に $\pm 0.5 \%$ 程度の精度で電解導 電率の測定が行えるようになってい る.したがって食塩水の詳細な導電率 データを揃えることにより，富水濃度 法をより合理的な形で行えるようにな る.

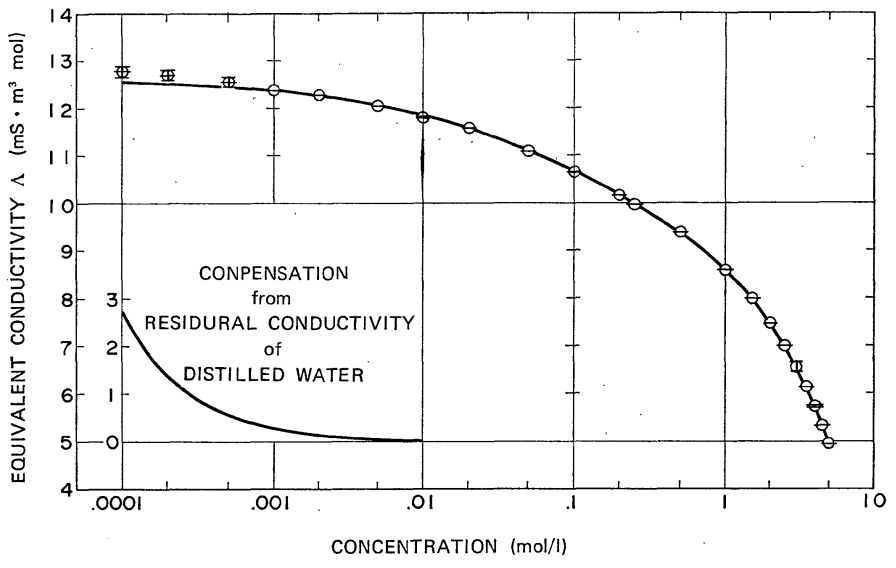

Fig. 2 Equivalent conductivity of brine

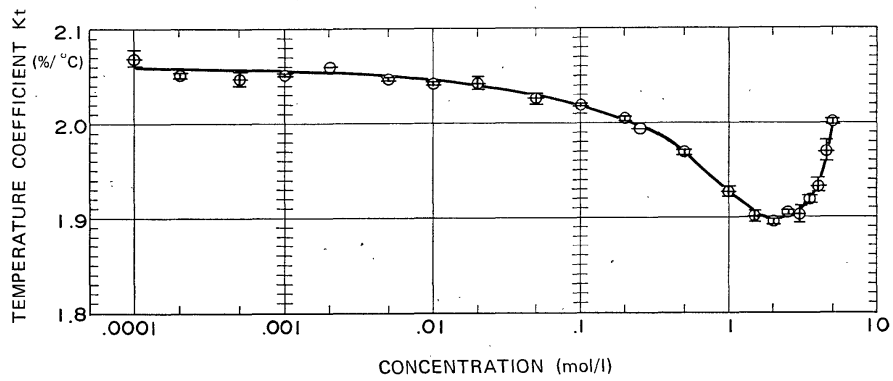

Fig. 3 Temperature coefficient of brine (1st order)

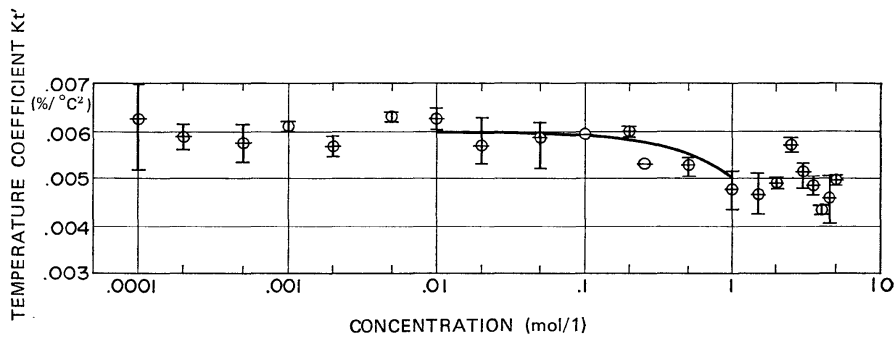

Fig. 4 Temperature coefficient of brine (2nd order) 
度補正量がかなり大きくなることが考えられる，例え ば $10^{\circ} \mathrm{C}$ で測定された電解導電率を $25^{\circ} \mathrm{C}$ の基準状態に 換算する場合の補正量は，測定值の $40 \%$ 強となる.

これらに比べ，電気化学便覧等 ${ }^{4), 5)}$ より得られる食 塩水の導電率データは, 特に $2 \mathrm{~mol} / l$ より濃い濃度で のデータが粗いととと，温度変化に対する特性が十分 に得られていないととにより, 塩水濃度法にそのまま 利用することはできない.

そこで, $0.1 \mathrm{~m} \mathrm{~mol} / l \sim 5 \mathrm{~mol} / l$ の濃度範团の食塩水 の電解導電率を, $10^{\circ} \mathrm{C} \sim 40^{\circ} \mathrm{C}$ の温度範囲で 詳細に測 定し，(2.2)式に基づいた合理的な手法で塩水濃度法 を実施するために必要な食塩水の導電率データの補 填，拡充を行った。

\section{2 食塩水の導電率特性 ${ }^{6)}$}

電解質の導電性は電解導電率 $\chi(=1 / \rho, \rho$ は抵抗率) により表わされ, 単位は $\mathrm{S} / \mathrm{m}$ が用いられる. また当 量導電率 $\Lambda\left(\mathrm{S} \cdot \mathrm{m}^{2} / \mathrm{mol}\right)$ は溶液の濃度を $c(\mathrm{~mol} / \mathrm{l})$ と すると

$$
\Lambda=\frac{\chi}{c} \cdot 10^{-3}
$$

Table 1 Equivalent conductivity and temperature coefficient of brine

(1) measured

(2) by empirical formulae (presented, table 2)

(3) Data from Chemical Hand Book ${ }^{4), 5)}$

\begin{tabular}{|c|c|c|c|c|c|}
\hline \multirow{2}{*}{$\begin{array}{l}\text { Concen- } \\
\text { tration } \\
C(\mathrm{~mol} / l)\end{array}$} & \multicolumn{3}{|c|}{$\begin{array}{c}\text { Equivalent Conductivity } \\
\Lambda\left(\mathrm{mS} \cdot \mathrm{m}^{2} / \mathrm{mol}\right)\end{array}$} & \multicolumn{2}{|c|}{$\begin{array}{c}\text { Temperature } \\
\text { Coef } \\
K_{t}\left(\% /{ }^{\circ} \mathrm{C}\right)\end{array}$} \\
\hline & (1) & (2) & (3) & (1) & (2) \\
\hline 0 & - & 12.645 & 12.645 & - & - \\
\hline 0.0001 & 12.783 & 12.557 & 12.559 & 2.068 & 2.059 \\
\hline 0.0002 & 12.701 & 12.522 & - & 2.051 & 2.059 \\
\hline 0.0005 & 12.564 & 12.452 & 12.450 & 2. 047 & 2.057 \\
\hline 0.001 & 12. 379 & 12.375 & 12.374 & 2. 051 & 2.056 \\
\hline 0.002 & 12.287 & 12.268 & - & 2.059 & 2.054 \\
\hline 0.005 & 12. 047 & 12.066 & 12.065 & 2.046 & 2.050 \\
\hline 0.01 & 11.803 & 11.853 & 11.851 & 2. 042 & 2.046 \\
\hline 0.02 & 11.580 & 11.576 & 11.576 & 2.042 & 2.040 \\
\hline 0.05 & 11.092 & 11.105 & 11.106 & 2.026 & 2.029 \\
\hline 0.1 & 10.684 & 10.674 & 10.674 & 2.018 & 2.017 \\
\hline 0.2 & 10.156 & 10. 173 & 10. 171 & 2.004 & 2.002 \\
\hline 0.25 & 9. 959 & 9. 980 & - & 1. 993 & 1.995 \\
\hline 0.5 & 9. 367 & 9.365 & 9.362 & 1.968 & 1.972 \\
\hline 1.0 & 8.575 & 8.581 & 8.576 & 1. 926 & 1.932 \\
\hline 1.5 & 7. 980 & 7. 976 & 7.986 & 1.901 & 1.907 \\
\hline 2.0 & 7. 459 & 7.455 & 7.471 & 1.895 & 1.895 \\
\hline 2.5 & 6.983 & 6.989 & - & 1. 904 & 1.894 \\
\hline 3.0 & 6.544 & 6.545 & 6.557 & 1.903 & 1.903 \\
\hline 3.5 & 6.131 & 6.127 & - & 1. 918 & 1.919 \\
\hline 4.0 & 5.725 & 5.724 & 5.723 & 1. 932 & 1.941 \\
\hline 4.5 & 5.323 & 5.332 & - & 1. 969 & 1.967 \\
\hline 5.0 & 4. 946 & 4. 947 & 4.946 & 2. 001 & 1. 997 \\
\hline
\end{tabular}

で与えられ，電気化学便覧等には各濃度における食塩 水の当量導電率が記載されている.

また電解導電率の温度特性としては, 食塩水に限ら ず一般に温度に対して線形に変化すると考えられ，

$$
\chi_{t}=\chi_{25} \cdot\left(1+K_{t} \cdot \Delta t\right)
$$

$$
\begin{aligned}
\text { ただし } \chi_{t} & : t{ }^{\circ} \mathrm{C} \text { におる電解導電率 } \\
\chi_{25} & : 25^{\circ} \mathrm{C} \text { におる電解導電率 } \\
k_{t} & : \text { 電解導電率の温度係数 } \\
\Delta t & : 25^{\circ} \mathrm{C} \text { からの温度差 }(=t-25) \\
t & : \text { 溶液の温度 }
\end{aligned}
$$

としている．Kt としては $2 \% /{ }^{\circ} \mathrm{C}$ の值が広く用いられ ているが電解導電率の温度による変化を詳細に測定す ると, $10^{\circ} \mathrm{C} \sim 40^{\circ} \mathrm{C}$ の温度範囲で $2 \%$ 程度の非線形な 変化が観測され，(3.2)式に $\Delta t$ の二次項を加えた

$$
\begin{aligned}
& \chi_{t}=\chi_{25} \cdot\left(1+K_{t} \cdot \Delta t+K_{t}{ }^{\prime} \cdot \Delta t^{2}\right) \\
& \text { ただし }, K_{t}{ }^{\prime}: \text { 電解導電率の二次温度係数 }
\end{aligned}
$$

によりその変化を良く表現できるととがわかった。

今回測定した電解導電率上り求淂食塩水の当量導 電率. $\Lambda$ と温度係数 $K_{t}, K_{t^{\prime}}$ の值を Fig. $2 \sim 4$ およ び Table 1 亿示す。 またてれらの測定值より求めた. $\Lambda, K_{t}, K^{\prime}{ }^{\prime}$ を近似する実験式及びその係数を Table 2

Table 2 Empirical formulae for the conductivity of brine

(1) conductivity of brine at $25^{\circ} \mathrm{C}$ $\chi_{t}=\chi_{75} \cdot\left(1+K_{t} \cdot \Delta t+K_{t^{\prime}} \cdot \Delta t^{2}\right)$ where $x_{t}$ : conductivity of brine at $t^{\circ} \mathrm{C}(\mathrm{S} / \mathrm{m})$ $\chi_{25}$ : conductivity of brine at $25^{\circ} \mathrm{C}(\mathrm{S} / \mathrm{m})$ $\Delta t:=t-25\left({ }^{\circ} \mathrm{C}\right)$

$K_{t}:$ temperature coefficient $\left({ }^{\circ} \mathrm{C}^{-1}\right)$ $K_{t^{\prime}}:$ 2nd order temp coefficient $\left({ }^{\circ} \mathrm{C}^{-2}\right)$ $\chi_{25}=\Lambda \cdot \mathrm{C} \cdot 10^{-3}$

where $\Lambda$ : equivalent conductivity of brine at $25^{\circ} \mathrm{C}\left(\mathrm{S} \cdot \mathrm{m}^{2} / \mathrm{mol}\right)$

$C$ : concentration of brine $(\mathrm{mol} / l)$

(2) empirical formulae for $\Lambda, K_{t}, K_{t}{ }^{\prime}$

i ) $0<C \leq 0.3$

$\Lambda=\left(A_{1}+A_{2} \cdot C^{1 / 2}+A_{3} \cdot C+A_{4} \cdot C^{3 / 2}+A_{5} \cdot C^{2}\right.$ $\left.+A_{6} \cdot C^{5 / 2}\right) \cdot 10^{-4}$

$K_{t}=B_{1}+B_{2} \cdot C^{1 / 2}+B_{3} \cdot C$

$K_{t}{ }^{\prime}=C_{1}+C_{2} \cdot C$

ii) $0.3<C \leq 5$

$\Lambda=\left(D_{1}+D_{2} \cdot C^{1 / 2}+D_{3} \cdot C+D_{4} \cdot C^{3 / 2}\right) \cdot 10^{-4}$

$K_{t}=E_{1}+E_{2} \cdot C+E_{3} \cdot C^{2}+E_{4} \cdot C^{3}+E_{5} \cdot C^{4}$

$0.3<C \leq 1$ では $K_{t^{\prime}}=C_{1}+C_{2} \cdot C$

$1<C \leq 5$ では $K_{t^{\prime}}=C_{3}$

(3) coefficient for the formulae

\begin{tabular}{l|r|c|c|c|c}
\hline \hline & \multicolumn{1}{c|}{$\mathrm{A}$} & $\mathrm{B}$ & $\mathrm{C}$ & $\mathrm{D}$ & $\mathrm{E}$ \\
\hline 1 & 126.45 & 0.020606 & 0.00006 & 113.55 & 0.020345 \\
2 & -88.52 & -0.001487 & -0.00001 & -30.094 & -0.0016685 \\
3 & 95.79 & 0.000377 & 0.00005 & 3.7372 & 0.00071837 \\
4 & -21.77 & & & -1.3840 & -0.000134714 \\
5 & -65.29 & & & & 0.000011019 \\
6 & 14.84 & & & & \\
\hline
\end{tabular}


に示す. $\Lambda$ の測定値のばらつきは $1 \mathrm{~m} \mathrm{~mol} / l \sim 5 \mathrm{~mol} / l$ の濃度範囲で $\pm 0.2 \%$ 程度であり, 電気化学便覧の値 とは $\pm 0.4 \%$ 以内の偏差があった.

Table 2 に示した実験式は，それぞれ濃度 “ $C$ ” の 高次式で表されて抢り, 食塩水の電解導電率と温度の 測定值より簡単な反復計算でその濃度を求めることが できるので, 塩水濃度法の基整データとしてそのまま 利用することができる.

\section{4. 流量測定実験}

\section{1 実験方法}

Table 2 亿示した食塩水の導電率データを基準にし て，何む準備実験を行わない新しい手法による流量測 定実験を行った。乙の実験では, 試薬の濃食塩水の濃 度と測定流の食塩濃度の変化を, それぞれの電解導電 率と温度より算出し，(2.2) 式に基づいた方法で流量 を算出しており, 希釈実験等の繁雑な準備実験は全く 行っていない.

実験はFig. 5 亿示す回流式開水路で行った. Fig. 6 亿示す 3 種類の注入管を用いて濃食塩水を注入し， 注入点の $6 \mathrm{~m}$ 下流に設けた測定点 (Fig. 5) で濃度分 布の違いを測定した. さらに回流式である利点を生か し，ポンプ部分を通過して完全に均一に混合された流 体部分が再び測定点に戻って来た時点で流量測定を行 い，本方法の究極的な測定精度の検討を行った.

\section{2 流量測定精度}

実験記録の一例を Fig. 7 亿示す．横軸に時間経過 を取り, 下側よりそれぞれ, 食塩水の注入量, 流路断 面中央での食塩濃度の変化及び流量の計算結果を示し ている. この実験例では，濃食塩水を約 $14 \mathrm{cc} / \mathrm{s}$ で約 8 分間注入する (注入管は (3))ととにより, 流路中の 約 $1 \mathrm{~m} \mathrm{~mol} / l$ の食塩濃度が約 $3.5 \mathrm{~m} \mathrm{~mol} / l$ に上昇して おり，乙の変化量とあらかじめ測定しておいた食塩濃 度(約 $2 \mathrm{~mol} / \mathrm{l}$ ) より計算される流量が約 $40 \mathrm{~m}^{3} / \mathrm{h}$ にな っているととが記録されている. 食塩水が完全に混合 された第 2 回目の測定時には, 約 1 分間の定常的濃度 要化丸゙得られ, 湘定値は図中に破線で示した超音波流 量計の平均流量とほぼ一致していることがわかる.

$20 \mathrm{~m}^{3} / \mathrm{h} \sim 50 \mathrm{~m}^{3} / \mathrm{h}$ の流量範囲で 23 例の 流量測定実 験を行い. 超音波流量計の值と比較を行った結果, 誤 差の度数分布図 Fig. 8 が得られた. 各流量毎の測定 值のかたよりとばらつきを Table 3 亿示す. 測定例は 少いが， 23 例中 16 例が， $\pm 2 \%$ 以内の誤差であった.

このように，今回提示した食塩水の導電率データを 基準に用いれば, 従来測定現場で行っていた繁雑で不 確実な希勫実験等の準備実験を全く行わずに，塩水濃

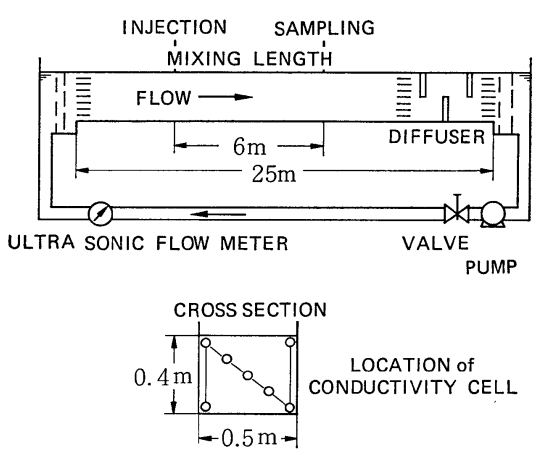

Fig. 5 Plan of the circulating channel
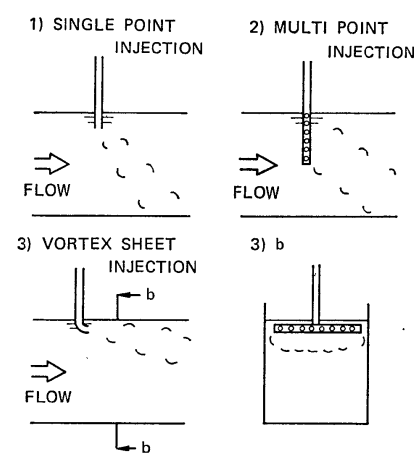

3) b

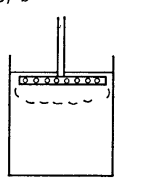

Fig. 6 Injection method
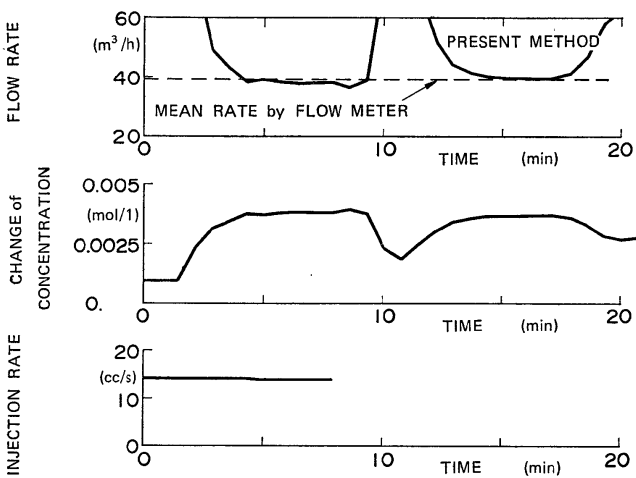

Fig. 7 Typical records of flow measurement

度法による流量測定を行えることが確認できた．ま た，乙の新しい手法による塩水濃度法は, 開水路流量 の測定法として十分な精度と再現性, 安定性をむって いるととも確認できた。

\section{3 食塩水注入方法の考察}

塩水濃度法を精度良く実施するには，注入された食 塩水が均一飞測定流中に拡散するととが重要な条件と なる. しかし試薬として用いる 1 ～ $3 \mathrm{~mol} / l$ の濃食塩 水の比重は 1.04 1.11 程度あり, 乱れの少い流れに 不用意に注入すると密度差により直ぐに水路底に沈ん でしまい，均一な拡散は行われにくい7)，Fig. 9 は 


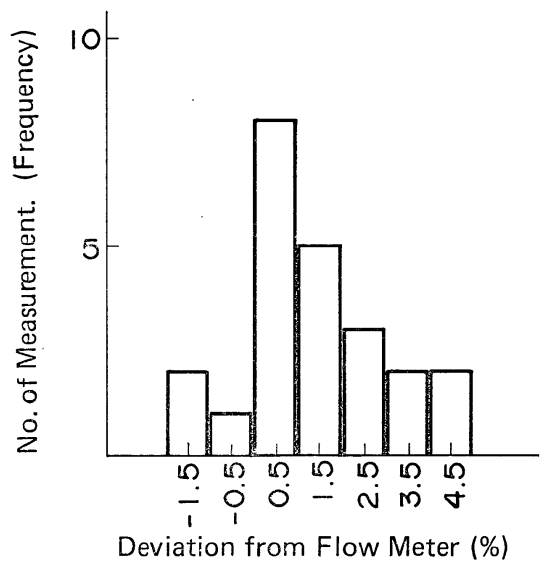

Fig. 8 Histogram of deviation of measured flowrates from those obtained by supersonic method

Table 3 Bias and dispersion of flow measurement

\begin{tabular}{c|c|c|c|c|c}
\hline \hline$Q\left(\mathrm{~m}^{3} / \mathrm{h}\right)$ & 20 & 30 & 40 & 50 & $20 / 50$ \\
\hline$q / Q$ & $\begin{array}{c}1 / 723 \sim \\
1 / 1358\end{array}$ & $\begin{array}{c}1 / 795 \sim \\
1 / 2038\end{array}$ & $\begin{array}{c}1 / 767 \sim \\
1 / 2864\end{array}$ & $\begin{array}{c}1 / 640 \sim \\
1 / 4348\end{array}$ & $1 / 640 \sim$ \\
$1 / 4348$ \\
\hline $\begin{array}{c}\text { number of } \\
\text { measure- } \\
\text { ments } \\
\text { (times) }\end{array}$ & 6 & 5 & 7 & 7 & 23 \\
\hline $\begin{array}{c}\text { avarage of } \\
\text { error (\%) }\end{array}$ & +1.14 & +1.82 & +1.20 & +1.37 & +1.37 \\
\hline $\begin{array}{c}\text { standard } \\
\text { deviation } \\
\text { (\%) }\end{array}$ & 2.68 & 1.18 & 1.24 & 1.07 & 1.59 \\
\hline
\end{tabular}

Fig. 6 に示した 3 種類の注入管による. 注入後 $6 \mathrm{~m}$ 地点での水深方向の食塩濃度分布の比較である。四 中, 縱軸に水深, 横軸には各実験毎に注入食塩水が完 全に均一に拡散した場合の濃度变化量 $(\overline{\Delta C})$ で無次元 化した濃度変化をとった，測定条件は 3 例ともほぼ同 一で, 約 $20 \mathrm{~m}^{3} / \mathrm{h}$ の流量に対し 約 $2 \mathrm{~mol} / \mathrm{l}$ の食塩水 を約 $7.5 \mathrm{cc} / \mathrm{s}$ で注入している.

（1）の水面付近で下向きに開口した注入管を用いた 場合は，水面付近ではほとんど濃度変化が見られず， 注入した食塩水は水路底に集中している。（2）の水路 断面中央上半分に垂直に配置したパイプの両側に，各 10 点の注入口を持つ注入管を用いると，（1）に比べて 拡散の範围は多少広がっているが，依然として濃度の 偏りが激しく, 単純な多点注入では均一な拡散は得ら れず，正確な流量測定は難しい。

これらに比べ(3)の注入管を用いた場合は注入食塩 水が広い範囲に拡散し，ほぼ均一な濃度分布が得られ ているととがわかる，ての今回考案した渦層拡散式注 入管は，水面直下に水平に配置した注入管の下流側に 20 点の注入口をむち, 注入管自身の発生する安定した 渦層の効果により, 注入食塩水のゆっくりとした沈降

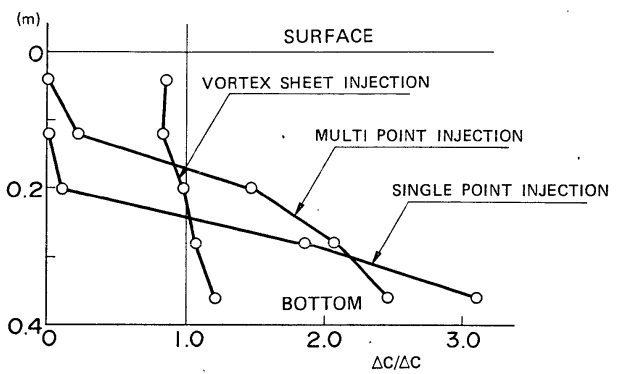

Fig. 9 Virtical distribution of injected brine, $6 \mathrm{~m}$ down stream

をむたらすむので，特に拡散促進を行わなくとむ均一 な濃度分布が得られている。流量測定現場で，十分な 拡散区間が得られず均一な濃度分布が得にくい場合に は，乙のような拡散効果の高い注入方法を選ぶこと も，測定精度の向上に効果がある.

\section{5. おわりに}

本研究で示した食塩水の導電率デー夕によって，任 意の食塩水の溇度をその電解導電率と温度より簡単に 求めることが可能となった。これらの実験式は 0〜5 $\mathrm{mol} / l$ の濃度範囲で $10^{\circ} \mathrm{C} \sim 40^{\circ} \mathrm{C}$ の温度範囲に適用で きる.

この食塩水の導電率データを基準に用いることによ り，塩水濃度法に必要であった測定現場での繁雑で不 確実な希釈実験等の準備手続きが，全て不要どなっ た。この 新しい手法による塩水㴗度法は測定の安定 性，再現性にむ優れており，容易に $\pm 3 \%$ 程度の精度 で流量測定が行えるととが確認できた.

塩水濃度法を実施する際に, 注入試薬の水路底部へ の偏りが生じ易く，精度の良い流量測定を行うために は何らかの拡散促進が必要であることが判明したが, 今回考察した渦層拡散式注入法む乱れの少ない水路で の拡散の均一化に効果のあるととがわかった.

打わりに，本研究は工業技術院試験研究所産業公害 防止技術研究の一環として行われ，実験の一部は中国 工業技術試験所の協力のあとに実施された．ここに記 して関係された諸氏に潹く謝意を表します。

\section{参 考 文 献}

1）板谷，服部，竹中：日本機械学会誌， 67-543，535/541 (1964)

2) D. S. Woffinden, and C. G. Clyde : Flow 1, I. S. A., $787 / 792(1974)$

3) I. S. O. 555 (1973), I. S. O. 2975/I (1974), I. S. O. 2975/II (1975)

4) 電気化学会編：電気化学便覧·新版 (丸善) 116/117 (1964)

5) 日本化学会編：化学便覧改訂 2 版 (丸善), 1184 (1964)

6）切田：計量研究所報告，33，1 (1984)

7）小宮, 内海, 渡辺, 切田：工業技術院特別研究報告集 58 年度版 (1983) 